\title{
Stepped-Up Progress On IFRS In Russia: History In The Making
}

David R. Borker, Ph.D., MAcc., CPA, Manhattanville College, USA

\begin{abstract}
Starting in May 2010 new Russian legislation and other events have raised expectations of an accelerated adoption of International Financial Reporting Standards (IFRS) starting January 2012. These events are examined in the context of the International Accounting Standards Board (IASB) and IFRS, the importance of adopting IFRS for Russia, relevant Russian cultural and geopolitical issues surrounding adoption, and the status of existing Russian Accounting Standards. The need for establishing support mechanisms, specifically, effective local standards setting bodies and a supportive institutional infrastructure is examined. Examples of strong standards setting bodies outside Russia in countries that have recently adopted IFRS are compared to standards setting bodies in Russia. The European Financial Reporting and Accounting Group (EFRAG), the European Commission's advisory group on IFRS, is considered as a potential support model and likely Russian counterparts are identified. Key success factors for Russia in successfully adopting IFRS are discussed.
\end{abstract}

Keywords: IFRS; Russia; IASB; EFRAG; Accounting; Reporting Standards

\section{INTRODUCTION}

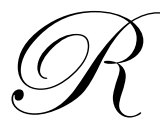

Tecent events in the Russian Federation have raised expectations that Russia is accelerating the process of the converging of its national reporting standards with International Financial Reporting Standards (IFRS). In particular, this includes the passage in 2010 of the Law on Consolidated Accounts (LoCA) requiring the use of IFRS for all consolidating financial reporting and the signing of Regulation 107 by Prime Minister Putin in February 2011 (Russian_Federation, 2010) (Russian_Federation, 2011). The latter affirms that law and sets into motion a series of activities to take place in the remainder of 2011 in to achieve expert examination of all documents representing IFRS in an acceptable Russian version to be approved by The Ministry of Finance (Minfin) of the Russian Federation for consolidated financial reporting of periods beginning on, or after, January 1, 2012. Critics within and outside Russia are not convinced that such a partial adoption of IFRS in Russia can be achieved within such a time frame.

In this paper the current process of Russia's movement toward adoption of IFRS is examined within the context of Russian cultural, governmental and private sector organizations with additional focus on examples of IFRS harmonization outside of Russia that may contribute to a better understanding of the factors that will lead to successful adoption of IFRS within Russia's currently planned time frame.

\section{INTERNATIONAL FINANCIAL REPORTING STANDARDS}

International Financial Reporting Standards (IFRS) originated from the foundation of the International Accounting Standards Committee (IASC) in 1973, and have evolved into what is fast becoming a single set of public financial reporting standards for the entire world. The stated goal of the current IFRS Foundation and the International Accounting Standards Board (IASB) is to "develop, in the public interest, a single set of high-quality, understandable, enforceable and globally accepted financial reporting standards based upon clearly articulated principles" (IASB, Adoption of IFRS, 2011). All major economies have established time lines to converge with or adopt IFRSs in the near future, and over 113 countries are following the path of harmonization of local reporting standards with the IFRS (IASB, 2011). Many of the countries have set 2011 as a major target for convergence with 
IFRS. Since the Norwalk Agreement of 2002 (FASB, 2002), the Financial Accounting Standards Board (FASB) in the United States has worked closely with the IASB to achieve financial reporting standards fully compatible with each another. Similarly, the U.S Securities and Exchange Commission (SEC) and the Committee of European Securities Regulators (CESR) published joint work plans in 2006 and in August 2008. The SEC approved for public issuance an updated roadmap that anticipates mandatory reporting under IFRS beginning in 2014, 2015 or 2016, depending on the size of the company. (SEC, 2008)

\section{IMPORTANCE OF IFRS FOR RUSSIA}

The Russian Federation has also been engaged in the harmonization process during the last ten years. However, its progress to date has not advanced as far as in certain other nations. In 2010, for example, the International Financial Standards Forum scored the Russian Federation at 39.17/ out of 100 for financial standards giving it a ranking of 53 among countries rated. In comparison, Australia and Canada scored 67.17 and 59.17, respectively, with rankings of 4 and 14. The Forum scored Russia on its Business Index at 7.07 out of 12 (ranking of 67) as compared with Australia 9.98 out of 12 (ranking 32) and Canada 9.23 out of 12 (ranking 46). (Financial_Standard_Forum, 2010) These indicators suggest that Russia has room for advancement in both its financial standards and overall business environment.

Russian full convergence with IFRS, including a stable infrastructure supporting the issuance of useful and reliable financial statements, would strengthen Russia's financial reputation in the world and could contribute to attracting much needed foreign capital into the country. Another factor to consider is that the Russian Federation is also still waiting for membership status in the World Trade Organization. Presumably, improved financial reporting transparency would complement its other efforts to qualify for membership.

\section{SPECIAL RUSSIAN CULTURAL, POLITICAL AND GEOGRAPHIC ISSUES}

It is undeniable that the cultural legacy of the Soviet Union, formally disbanded in 1991, has a profound effect upon all Russian individual citizens, non-profit and commercial organizations and political organs of power. At all levels, there is a memory of being part of a large union of republics of which Russia, and Moscow in particular, was the center. This sense of being larger than a single country may help to explain why Russian politicians may at times compare themselves with the European Council (EC) when looking for organizational solutions to their efforts to achieve harmonization with IFRS.

Pricewaterhouse Coopers (PWC) points out that in Russia, the term accounting means primarily bookkeeping rules, while internationally it refers to financial reporting. (PricewaterhouseCoopers Russia, 2009) Actually the Russian word for an accountant "bukhgalter," which is derived from the German "Buchhalter," means literally bookkeeper and accounting, "bukhgalterskij uchet," means literally "bookkeeping count." In the Marxist rhetoric of the Bolsheviks "workers and bookkeepers" are frequently cited as the foundation of the new social order. In the command economy of the Soviet Union, accounting served primarily as a planning and monitoring tool to track the progress of state organizations relative to their predetermined economic plans. State accounting was highly formal and prescriptive in nature with little orientation toward the economic substance of transactions. Many costs were not taken into account, including costs of land, depreciation, and energy. (Horwitz, 1963) These attitudes carried over to individuals, who, until quite recently received free or nominally priced energy. That world has changed radically, but people's attitudes change more slowly. If the ultimate goal is to reform Russian Accounting Standards (RAS) so that individuals in Russia, as well as foreign investors, can read and comprehend financial statements to some reasonable degree when making decisions, it is necessary that public education, as well as, professional training of accountants and auditors be developed further.

With the rise of private for profit commercial organizations, the new Russian government had to rely more and more on business and individual taxation to fund the state apparatus. Given the legacy of corruption carried forward during the first decades of the new Russia, many businesses are tempted to underreport taxable income to avoid Russia's substantial business tax rates. Accounting rules of Russian taxing authorities have had a strong impact on financial reporting rules in Russia. (Tohmatsu, 2009) 


\section{RUSSIAN ACCOUNTING STANDARDS (RAS) - 1996 TO MID-2010}

Existing Russian Accounting Standards (RAS) consist of laws enacted by the Russian Federation, and rules and regulations issued by The Ministry of Finance of the Russian Federation (Minfin). This includes the Federal Law on Accounting (Federal Law No. 129-FZ of the Russian Federation) signed by Boris Yeltsin in 1996 and Russian Accounting Standards or PBUs ( Polozheniya po Bugalterskomu Uchetu) developed and approved by Minfin to provide additional interpretation and guidance, and orders of Minfin on management, maintenance and reporting of accounting records. (Ernst\&Young, IFRS, US GAAP and RAP, Comparison and Basics, 2009)

In Order No. 180 Concept of the Development of Accounting and Financial Reporting in the Russian Federation for the Mid-term issued in 2004 (MinFin, Order No. 180 Concept of the Development of Accounting and Financial Reporting in the Russian Federation for the Mid-term, 2004), Minfin indicated two main directions of the accounting reform in Russia - gradual introduction of IFRSs for consolidated accounts for different types of companies, and elimination of differences between PBUs and IFRS (convergence). In 2004, Minfin introduced a draft Federal Law on Consolidated Financial Statements which would require use of IFRS for consolidated financial statements of public companies as early as 2007. Final ratification of this law remained stalled in the Russian legislature, the Duma, through May of 2010. (Gethin, 2006)

Banks operating only in the Russian Federation maintain their accounting and reporting of financial statements in accordance with the rules and regulations set by the Central Bank of Russia. New Regulation No. 302$\mathrm{P}$ was developed as part of the harmonization in relation to IFRS and became effective on January 1, 2008. This regulation basically calls for the use of IFRS by all Russian banks. Despite this regulation, the International Monetary Fund (IMF), in a 2010 report, points out that "banks do not report consistently according to IFRS, constraining risk monitoring and limit international comparability of bank balance sheets." (IMF, 2010) Another governmental body that has influence over Russian accounting is The Federal Financial Markets Service (FFMS), although this primarily consists of enforcement of existing reporting rules and certain special disclosure requirements.

While many of RAS's general principles, conceptual frameworks and accounting standards are similar to IFRS early accounting standards, Ernst\&Young notes that RAS does not provide guidance on several key areas, including consolidations, business combinations, purchase price allocation, impairment of property, plant and equipment, financial instruments, share-based payments, employee benefits and pension plans (Ernst\&Young, 2009). Russian accounting differs from IFRS in many significant ways. For example, in contrast to IFRS, Russian financial statements are prepared on a historical cost basis and do not widely apply the 'fair value' concept, finance leases are usually not capitalized, assets are normally not tested for impairment, and provisions for bad debt are generally nonexistent. Many RAS differences with IFRS relate to Russian concern for making financial accounting standards conform to the demands of its federal tax code. Thus, the book useful lives of fixed assets tend to conform to the useful lives specified for tax purposes, and revenue and expense are only recognized after all the preceding primary documentation supporting the transaction has been received, in accordance with the tax rules. In short, Minfin's envisioned gradual elimination of differences between PBUs and IFRSs still has a long way to go.

\section{SIGNIFICANT EVENTS IN RUSSIAN ACCOUNTANCY SINCE MAY 2010}

In July 2010, Federal Law 208F-3 "On Consolidated Financial Statements," was finally passed by the Russian Duma and signed by President D. Medvedev on July 27, 2010, effective August 10, 2010. The law calls for use of IFRS for a consolidated financial reporting without specifying a precise time frame. (Russian_Federation, 2010)

On February 27, 2011, Prime Minister Putin issued Regulation 107, which, in reference to the previously passed Law on Consolidated Financial Reporting, affirms the implementation of IFRS and calls for completion of an expert process of examination of all IFRS documents and their endorsement as applicable for implementation in the Russian Federation. The order specifies that an 'organ' or body of experts must be selected by Minfin through a competitive process and that this body will examine all IFRS documents in Russian for their implementation in Russia. Regulation 107 set a time frame of 40 days from selection and beginning of operation for the expert body's 
examination and presentation of all Russian language documents endorsed by it as implementable in the Russian Federation to Minfin. Final decision on the implementation of IFRS is to be made by Minfin with agreement of The Federal Financial Markets Service (FFMS) and The Central Bank of the Russian Federation (CBR) with even shorter time frames set for approval. (Russian_Federation, 2011)

On April 8, 2011, in accordance with Regulation 107 and The Law on Consolidated Financial Statements, Minfin issued Order 41 calling for the formation of a committee headed by Minfin, and an invitation of competitive applications from professional organizations for the purpose of selecting an expert body to examine in Russian all documents of IFRS for applicability in the Russian Federation. (MinFin, Prikaz MinFina Rossii ot 08-04-2011 No. 41, 2011)

On April 29, 2011, Minfin entered into an agreement with the IASB Committee on International Financial Reporting Standards permitting it sole right to the Russian version of IFRS in the territory of the Russian Federation and giving Minfin rights to an official Russian text, to which it would hold copyright, and could be used in all IFRS audits in Russia. (PWC, 2011)

On June 14, 2011, at a session of the Presidium chaired by Prime Minister Putin, Minister of Finance Alexei Kudrin stated with regard to IFRS, that the main task was to complete the process of adaptation of IFRS before the end of the 2011 "and if the process is completed before the end of the year, already next year - 2012 - all companies that have consolidated reporting will report using IFRS. In 2013 for 2012 [activity] for the first time in Russia all consolidated groups will report in this way in the required manner." (Minfin, Vyskazyvaniya rukovodstva, 2011) Although hardly a guarantee of success, this statement clearly expresses the intention of Minfin to begin partial IFRS reporting for the 2012 reporting period.

On July 7, 2011, Minfin issued an order designating the organization "National Organization on Financial Accounting and Reporting Standards" (NSFO) to be the expert body to examine IFRS for implementation in Russia. (Minfin, Soobschenie ob opredelenii ekspertnogo organa dlya provedeniya ekspertizy primenimosti dokumentov, vkhodyashchikh v sostav MSFO na territorii RF, 2011). NSFO was actually the only organization that submitted an application in the competition for this role. On July 18, Minfin and the NSFO entered into an agreement whereby all documents relating to IFRS are given over to the NSFO for expert examination of their applicability in the Russian Federation in a definitive Russian translation. Since these events, Minfin has placed a downloadable scorecard on its official website summarizing for each IFRS document the status of the NSFO's progress to date. (Minfin, Soobschenie ob opredelenii ekspertnogo organa dlya provedeniya ekspertizy primenimosti dokumentov, vkhodyashchikh v sostav MSFO na territorii RF., 2011) Columns are also provided for Minfin review and joint approval with the CBR and FFMS and for final publication of the definitive Russian language version of all IFRS documents on a special Minfin website. (MinFin, Informaciya o khode priznaniya MSFO I ikh raz'yasneniy na territorii RF, 2011)

\section{RUSSIA'S NEED FOR SUPPORT AND INFRASTRUCTURE - LOOKING OUTSIDE RUSSIA}

Following Alexei Kudrin's June 14 announcement of the switch to International Financial Reporting Standards (IFRS) for consolidated entities in 2012, Senior Moscow PWC partner Galina Ryltsova asserted that a "support mechanism for adopters" will be the key to future success in the process. Ryltsova stressed the importance of local standard setting bodies in such a support mechanism, citing their role in the harmonization process in other countries such as Australia and Canada. "They [local standard setting bodies] identify significant implementation issues and engage in dialogue with the staff of the IASB with respect to their countries' specific concerns and issues." She also asserted that Russia has a long way to go to have in place an effective institutional infrastructure to implement IFRS in Russia, while at the same time noting the Russian government had reportedly invited professional organizations to put themselves forward as an endorsement body for Russia similar to the European Financial Reporting Advisory Group. This is no doubt a reference to Minfin's invitation for competitive applications pursuant to Order 41. (PWC, 2011) 


\section{EXEMPLARY MODELS OF LOCAL STANDARD SETTING BODIES}

In the search for role models for Russia, one might consider accounting standard setting bodies in Canada and Australia. Although both are members of the British Commonwealth, Canada and Australia differ from one another on the issue of private versus public interest as the dominant emphasis in standard setting. Canada places emphasis of private interests, seeing the role of accounting to be to provide facts about a firm's performance and financial position. Consistent with this position, standards and policy should be free from political interference and, ideally, governments should not be involved in the process of regulating accounting practices. The independent Accounting Standards Board of Canada (AcSB) is the country's official standard setting body and has the authority to develop and establish standards and guidance governing financial accounting and reporting for Canadian companies, and not-for-profit organizations. (AcSB, 2011)

Australia follows a more political and legalistic path emphasizing protection of the public interest. In Australia, the accounting standard setting body is the Australian Accounting Standards Board (AASB). The AASB and its supervisory AASB Oversight Council are both part of the Australian Federal Government (AASB, 2011). Furthermore, accounting and reporting practices are clearly regulated by Australian federal statutes and regulatory authorities. The Corporations Act of 2001 regulates accounting and reporting practices of companies, registered schemes and disclosing entities in Australia. (Australia 2011)

There are obvious similarities to the Canadian AcSB standard setting process. Like the AcSB, the AASB stresses transparency and makes all discussions documents available on its website. Both Canada and Australia have one authorized standard setting body that has the authority to set standards on its own. In practice, each standard setter makes every effort to obtain comments and feedback at various stages in the standard setting process from a variety of stakeholders. Another important aspect of both the Canadian and Australian standard setting bodies is their energetic efforts to identify implementation issues with regard to adoption of IFRS and their regular involvement in discussions with IASB staff to discuss and resolve such issues. (AcSB, Liaison with the IASB and Other Accounting Standard Setters, 2011). Of these two examples, one would think that Australia would offer a more acceptable model for Russia, given its acknowledgement of a governmental basis for standard setting, implementing and assuring compliance with accounting standards.

\section{WHO IS RUSSIA'S ONE AUTHORIZED STANDARD SETTER?}

How does the standard setting situation in Canada and Australia compare to that in the Russian Federation? The first question is to what degree we can clearly identify one organization that is the undisputed financial accounting standard setter for the Russian Federation.

As discussed earlier, Russian accounting has a strong governmental legal base within which the Ministry of Finance is authorized to have decision making power. This is upheld by the recent Law on Consolidated Financial Reporting and Regulation 107. The decision making powers of Minfin are, nonetheless, limited by the legal constraint that it find agreement from the CBR and FFMS. Minfin clearly has played the key role in the standard setting process up until now through its issuance of PBUs, discussion documents and draft legislation on adoption of IFRS and the strategic approach to achieving convergence,

Of these governmental bodies, Minfin appears to be the most likely candidate as a standard setter. Minfin has showed by its actions, its intention to continue to play a central role in accounting standard setting and the process of convergence with IFRS. Minfin has submitted numerous discussion papers and proposals for laws on IFRS and the accounting standard setting process in Russia.

At the same time, from early on, Minfin has envisioned itself as a state body that approves accounting standards prepared by experts outside of government. In 2005, Minfin posted on its website the Draft Law on Official Accounting which, according to the Ministry, was a step in the implementation of the "Concept of MidTerm Development of Accounting and Financial Reporting in Russian Federation." (Buza, 2006) In addition to the introduction of unified accounting requirements and principles of legal regulation, this draft law made a distinction between the role of governmental and non-governmental bodies. According to the draft law, a number of self- 
regulatory bodies were to be given responsibility to prepare accounting standards which would be approved for application by governmental bodies. Since the issuance of Regulation 107 in February 2011, Minfin has entered into direct negotiations with the IASB for the purpose obtaining rights to the Russian language translation copyright of all SFRS written materials and has requested educational and training materials.

Is Minfin, through its executive and legislative authority, Russia's accounting standards setter? The answer is both yes and no. Although Min-Fin is a huge organization with a whole section of accounting specialists, it has chosen to collaborate regularly with professional self-regulating accounting organizations outside of the government. Non-governmental self-regulating professional organizations in Russia include the Institute of Professional Accountants and Auditors of Russia (IPAR), the Russian Collegium of Auditors (RCA), The International Association of Accountants and Auditors "Sodruzhestvo" (AAAS), and, of course, the "The National Organization for Financial Accounting and Reporting Standards" (NSFO). Of the above organizations, Minfin has collaborated most closely with NSFO and the designation of NSFO as the organ of expertise in a competition where no other body even chose to compete, would suggest that NSFO was favored by Minfin to be the body most capable of carrying out the required examination of IFRS in accordance with Regulation 107.

One question remains. If Minfin shares aspects of its standard setting role with NSFO, which body ensures that all important implementation issues regarding IFRS are raised, fully discussed and resolved in a proper manner? NSFO was established in 2003 in response to the call for accounting reform and IFRS. Its name acronym, not accidentally, sounds like the acronym for the Russian version of IFRS - MSFO/MCФO). NSFO can be described as a proactive organization which engages in many projects, papers, round tables and seminars relating to IFRSs and existing Russian PBUs. Unlike its other private sector counterparts, NSFO is not a rank and file professional organization, but more of a large think tank of accounting and other technical specialists having a strong set of private sector sponsors. NSFO has demonstrated its independence from Minfin in the past expressing its disagreement with Minfin proposals. In 2006, for example, NSFO rejected Minfin's proposal to introduce IFRS for consolidated reporting without dealing with other types of reporting (IPP, 2010). NSFO already has a long record of collaborating and engaging in discussions with IASB on reporting issues in Russia.

Minfin also interacts with IASB, but more on the level of control issues. As discussed earlier, Minfin pursued and finally obtained from IASC the copyright for the Russian translation of all IFRS documents for use in Russia and other Russian speaking countries. Russian is the second language in most of the former Soviet republics, and this would position the Russian Federation as a major knowledge source and influence on accounting practices in many of these new countries. Its dealings with IASB are more often over legal or legislative issues than accounting principles.

NSFO appears to be the more proactive organization as compared with Minfin, yet Minfin is the true standard approver and can at any time choose to not involve NSFO in the ongoing standard setting process. Furthermore, Minfin is a highly visible political organization reporting to the executive branch and subject to changes in ministers with potentially different standard setting philosophies. Consider that all of the achievements in moving toward adoption of IFRS have been championed by one minister - Alexei Kudrin, who has been Russia's Minister of Finance for the last eleven years.

\section{THE EUROPEAN FINANCIAL REPORTING ADVISORY GROUP (EFRAG)}

As noted earlier, the Russian government's invitation of various professional organizations to apply competitively for the role of the expert advisory body that would examine and endorse all IFRS documents in their Russian translation is viewed by some as an attempt at creating an expert endorsement body analogous to the European Financial Reporting Advisory Group (EFRAG) (PWC, 2011). The implications of this comparison might best be addressed by reviewing the major functions of EFRAG and then exploring potential applications for Russia's IFRS support infrastructure.

It is important to note that EFRAG comprises two major aspects important to the infrastructural needs of Russia in its migration to IFRS. The first is its role as an expert advisor and endorser of IFRS capable of addressing all conceptual and technical issues arising out of the introduction and ongoing evolution of IFRS. This role requires 
that EFRAG have the capacities of a large and independent professional consulting/research organization. This is evidenced by EFRAG's numerous advisory and analytical activities which include production of ongoing research projects and papers, holding of special conferences and symposia and other activities that fulfill its advisory function for the governing European Council (EC), the individual standard setting bodies of the member EU countries and, more broadly, commercial organizations, governments and standard setting bodies worldwide. EFRAG's second role is that of being a broadly sponsored organization uniting and reflecting the needs and interests of its sponsor member-stakeholders who represent major commercial and professional sectors within the EU region.

EFRAG was established in 2001 to assist the European Commission in the endorsement of International Financial Reporting Standards (IFRS), as issued by the International Accounting Standards Board (IASB), by providing advice on the technical quality of IFRS. EFRAG is a private sector body sponsored by European organizations prominent in the European capital markets, and known collectively as the 'Member Organizations.' (EFRAG, 2011) These are:

$\begin{array}{lll}- & \text { BUSINESSEUROPE } & \text { European Business Federations } \\ - & \text { FEE } & \text { Federation of European Accountants } \\ \text { - } & \text { EBA } & \text { European Insurance and Reinsurance Federation } \\ \text { - } & \text { ESBG } & \text { European Banking Federation } \\ \text { - } & \text { EACB } & \text { European Savings Banks Group } \\ \text { EFAA } & \text { European Association of Co-operative Banks } \\ & & \text { European Federation of Accountants and Auditors }\end{array}$

The work of EFRAG is overseen by an independent Supervisory Board. The EFRAG Supervisory Board's main duties include selecting membership, and overseeing the work of the EFRAG Technical Expert Group that conducts various projects and the EFRAG Planning and Resource Committee, monitoring cooperation with National Standard Setters, and ensuring proper funding for EFRAG.

The EFRAG Supervisory Board consists of senior professionals and leaders with an interest in the global development of financial reporting and with an appropriate balance of professional backgrounds, e.g., users, preparers and accountants, and geographical spread. The Supervisory Board is appointed by the EFRAG General Assembly, following recommendations of the EFRAG Governance and Nominating Committee. This Committee is comprised of four representatives of the General Assembly and three representatives of National Funding Mechanisms (EFRAG, 2011). EFRAG's role is both proactive and reactive. Below is a list of major responsibilities.

- $\quad$ Provide advice to the European Commission on the endorsement of new or amended IFRSs and IFRS interpretations;

- $\quad$ Comment on proposed IFRSs and IFRS interpretations, IASB discussion papers and other consultative documents;

- $\quad$ Attend various IASB Working Group meetings as observers;

- Maintain regular contacts with the IASB through meetings with its chairman. IASB Board members and senior staff participate in each EFRAG TEG meeting;

- Work closely with European National Standard Setters (NSS) on various activities designed to encourage debate in Europe on accounting matters to develop European views on issues of importance and enhance the quality of Europe's input to the IASB (see also section on Proactive Activities);

- $\quad$ Meet quarterly with the European National Standard Setters (NSS) to exchange views;

- $\quad$ Meet quarterly with European User representatives in the EFRAG User Panel;

- $\quad$ Participate in the World Standard Setters meetings (organized by the IASB);

- $\quad$ Participate in the meetings of the former IASB liaison standard setters where technical issues of a proactive nature are discussed. (EFRAG, 2011)

Table 1 lists the member organizations of EFRAG and considers hypothetically what Russian organizations might potentially play analogous member sponsor-stakeholder roles if an organization parallel to EFRAG were formed in the Russian Federation. 
Table 1 Comparison of actual EFRAG Infrastructure and possible options for Russian Federation

\begin{tabular}{|c|c|}
\hline $\begin{array}{c}\text { European Commission } \\
\text { ACTUAL } \\
\end{array}$ & $\begin{array}{l}\text { Russian Federation } \\
\text { POSSIBLE }\end{array}$ \\
\hline $\begin{array}{l}\text { European Business Federations (BUSINESSEUROPE) } \\
\text { - Main horizontal business organization at EU level }\end{array}$ & $\begin{array}{l}\text { Russian Social Organization of Small and Medium Sized } \\
\text { Enterprises "Opora Rossii". }\end{array}$ \\
\hline $\begin{array}{l}\text { Federation of European Accountants / Federation des } \\
\text { Experts-Comptables Européens (FEE) }- \text { Representative } \\
\text { organization for the accountancy profession in Europe }\end{array}$ & $\begin{array}{l}\text { Institute of Professional Accountants and Auditors of Russia } \\
\text { (IPAR) } \\
\text { Russian Collegium of Auditors (RCA), Member IFAC } \\
\text { National Federation of Consultants and Auditors (NFKA) now } \\
\text { part of RCA above. } \\
\text { International Association of Accountants and Auditors } \\
\text { "Sodruzhestvo" (ABiAS) } \\
\text { National Organization for Financial Accounting and Reporting } \\
\text { Standards (NSFO) }\end{array}$ \\
\hline $\begin{array}{l}\text { European Insurance and Reinsurance Federation (CEA) } \\
\text { - Representative of all types of insurance and reinsurance } \\
\text { undertakings }\end{array}$ & All Russian Union of Insurers (VSS) \\
\hline $\begin{array}{l}\text { European Banking Federation (EBF) } \\
\text { - Organization of the European banking sector }\end{array}$ & $\begin{array}{l}\text { Association of Russian Banks (ARB) } \\
\text { Association of Regional Banks RF (Association "Russia") }\end{array}$ \\
\hline European Savings Banks Group (ESBG) & No equivalent \\
\hline European Association of Co-operative Banks (EACB) & No equivalent \\
\hline $\begin{array}{l}\text { European Federation of Accountants and Auditors (EFAA) } \\
\text { - European Economic Interest Group of experienced, } \\
\text { independent accounting, tax and business advisory firms }\end{array}$ & $\begin{array}{l}\text { Big } 5 \text { accounting firms in Russia } \\
\text { FBK (Russian accounting and auditing firm) } \\
\text { AFK (Russian accounting information technology firm) }\end{array}$ \\
\hline
\end{tabular}

\section{EUROPEAN BUSINESS FEDERATIONS (BUSINESSEUROPE)}

BUSINESSEUROPE's members are 41 central industrial and employers federations from 35 countries, working together to achieve growth and competitiveness in Europe. The organization represents small, medium and large companies (BUSINESSEUROPE, 2011). It is difficult to find a sponsor organization fully comparable to BUSINESEUROPE. However, General Russian Social Organization of Small and Medium Sized Enterprises "Opora Rossii" is a possible candidate. "Opora Rossii" is a large organization with strong political ties to the majority political party "United Russia." As such, it cannot be seen as entirely non-political.

\section{FEDERATION OF EUROPEAN ACCOUNTANTS}

The Federation of European Accountants or Fédération des Experts-comptables Européens (FEE) is an international non-profit organization based in Brussels that represents 45 institutes of professional accountants and auditors from 33 European countries, including all of the 27 EU Member States. FEE has a combined membership of more than 700.000 professional accountants, working in different capacities in public practice, small and big accountancy firms, businesses of all sizes, government and education, who all contribute to a more efficient, transparent and sustainable European economy. (FEE, 2011) One of its potential counterparts in Russia is IPAR, the Institute of Professional Accountants and Auditors of Russia [Institut professional'nykh bukhgalterov I auditorov Rossii (IPBRossiya)], founded in 1997 in response to the call for accounting reform and international standards. IPAR has a membership in excess of 100,000 and over 1000 branch organizations (IPAR, 2011). IPAR provides extensive educational and certification programs in the field, having 1,500 certified instructors, 65 territorial institutes, and 400 methodology study center within Russia. Annually over 10,000 candidates take exams for membership in IPAR and, since its establishment, IPAR has provided professional training to over 220,000 professional accountants. 
Another counterpart worthy of mention is the Russian Collegium of Auditors (RCA) [Rossiysaya kolegiya Auditorov (PKA)] (RCA, 2011). RCA is a self-regulating body unifying Russian auditors registered with Minfin. RCA was established in 1992 as the continuation of an earlier organization registered with the Ministry of Justice. The RCA includes the former National Federation of Consultants and Auditors (NFKA) as well as numerous regional associations of accountants and auditors throughout Russia. RCA has 3,300 direct members and 786 member organizations.

The International Association of Accountants and Auditors "Sodruzhestvo" (AAAS) established in 1989 [mezhdunarodnaya obschestvennaya organizaciya Assosiyaciya Bukhgalterov i Auditorov "Sodruzhestvo" (AbiAS)] is the oldest Russian accounting organization, headquartered in Moscow. After the end of the Soviet Union it stills retains members in eight former Soviet republics besides Russia. (AAAS, 2011)

Finally, the NSFO, discussed above in some detail, is more of a professional expert organization for examining and researching accounting standards and policies rather than a rank and file professional organization like the others above. NSFO's governing board and council of advisors reflects a broad sponsorship base of commercial and professional organizations similar to that of EFRAG itself. In fact, several of the Russian organizations listed in Table 1 as counterparts to EFRAG's sponsor members are sponsors on the board of NSFO.

\section{EUROPEAN INSURANCE AND REINSURANCE FEDERATION (CEA)}

The CEA is the European insurance and reinsurance federation. Through its 34 member bodies - the national insurance associations - the CEA represents all types of insurance and reinsurance undertakings, e.g. panEuropean companies, monoliners, mutuals and SMEs. The CEA, which is based in Brussels, represents undertakings that account for around 95\% of total European premium income. Insurance makes a major contribution to Europe's economic growth and development (CEA, 2011). The closest Russian counterpart to this organization in EFRAG is the All-Russia Union of Insurers (VSS) founded in 1994 with the entrance of many private insurance and reinsurance companies into the Russian market. The union represents professional participants of the insurance market at a federal level. Its mission is to coordinate activity of the members and to represent and protect their general interests in relation to other Russian and foreign organizations and governmental authorities. (VSS, 2011)

\section{EUROPEAN BANKING FEDERATION (EBF)}

The European Banking Federation (EBF/FBE in French) is an organization of the European banking sector, representing the interests of over 5000 European banks in 31 countries with combined assets of over 30,000 billion Euro and around 2.4 million employees. It was established in 1960. EBF acts as a forum where member initiatives are proposed and debated and as a dialogue partner for the European institutions in laying out the relevant legislation in the banking sphere. It supports the European unification process and safeguards European banking interests in Brussels, Belgium (EBF, 2011). The closest counterpart to The European Banking Federation (EBF) is the Association of the Russian banks (ARB). It is a private, non-profit organization uniting commercial banks and other credit institutions, as well as other organizations whose activity is connected with functioning of the credit-financial system of the Russian Federation. It was established in 1991. The ARB has 712 member institution including 80\% of Russian banking institutions representing $92 \%$ of combined bank capital, and $93 \%$ of the assets of the entire banking system. It represents the interests of large, medium and small sized institutions. The ARB works closely with the Central Bank of Russia. It appears to be closest in size and coverage to the EBF. (ARB, 2011)

The Association of Regional Banks RF, now Association "Russia," established in 1990, was the first bank association on the federal level. It claims to have more than 450 institutional members. In spite of its original name, now called for short the Association "Russia" [Associyaciya "Rossiya"], it can hardly be considered as simply a regional banking organization, given that its members include very large networking credit establishments operating on a national scale, banks with foreign capital participation, as well as the small and average regional banks. "Rossiya" describes itself as having in recent years "closed ranks with the Russian bankers, built relationships between bank business and authority" and as "effectively pursuing a policy of protection of interests of banks, solving regional problems at a federal level, actively assisting formation of legislative and normative base of activity of the credit organizations of the country" (translated from Association's Russian website). (AS, 2011) Although smaller than ARB, it appears to be highly proactive and is represented on the NSFO board. 


\section{EUROPEAN SAVINGS BANKS GROUP (ESBG)}

The European Savings Banks Group is a European banking association representing 26 members from 26 countries (EU and non-EU), comprising approximately 870 individual savings and retail banks. These institutions operate 84,000 branches and employ 971,000 people. The European Savings Banks Group was founded in 1963 as the 'Savings Banks Group of the European Economic Community'. The association changed its name to European Savings Banks Group in 1988. ESBG is the sister organization of the World Savings Banks Institute. Both organizations are managed in Brussels by a WSBI-ESBG Joint Office. ESBG represents the interests of its members vis-à-vis the EU Institutions and fosters cooperation between them. To this end, it defines and expresses the position of its members in matters related to the European financial services industry (ESBG, 2011). There is no equivalent private organization in Russia, in that the entire Russian Savings Bank network (Sberbank) is run by the Russian federal government.

\section{EUROPEAN ASSOCIATION OF CO-OPERATIVE BANKS (EACB)}

The European Association of Co-operative Banks (EACB) is the supranational body for co-operative banks, with member national governing bodies in 23 countries and an associate member in Switzerland. The mission of the EACB is to represent and promote the interests of its members and co-operative banks in general. It lobbies the European institutions and informs its members of relevant European initiatives susceptible of impacting the banking sector. It also develops common positions (in the form of 'position papers') on European policy issues (EACB, 2011). There is a co-operative movement in Russia, but no equivalent industry organization could be found.

\section{EUROPEAN FEDERATION OF ACCOUNTANTS AND AUDITORS (EFAA)}

The European Federation of Accountants and Auditors for small and medium-sized enterprises (EFAA) is an umbrella organization for national accountants and auditors' organizations whose individual members provide professional services primarily to SMEs within the European Union and Europe as a whole. It was founded in 1994. EFAA has 12 members throughout Europe representing over 200,000 accountants and auditors. EFAA is a member of the European Union of Crafts Small and Medium-sized Enterprises (UEAPME). As compared with the FEE, EFAA is a smaller organization for specialized private accounting and consulting organizations. It is a very influential group, as evidenced from the fact that EFAA claims to be the founding father of EFRAG itself (EFAA, 2011). Their closest equivalent would be the Big Four Accountings firms already in Moscow along with the Russian accounting firm FBK. All of these organizations are currently represented on the NSFO Board.

\section{WHAT CONCLUSIONS CAN BE DRAWN FROM THE EFRAG COMPARISON?}

At the most superficial level, one might imagine that the Russian government's search for an advisory body similar to EFRAG reflects the notion that the Russian government, by virtue of its size and influence is comparable to European Commission (EC), even though Moscow, once the capital of numerous republics, is now the center of a single country. EFRAG coordinates with and advises the standard setters of all the EU countries. This might be viewed as unnecessary, given that there is only one standard setter in Russia, i.e., Minfin, or, as discussed earlier Minfin sharing its role, if not its power, with an expert advisory body.

On the other hand, NSFO, Minfin's designated expert advisory body, at least for the IFRS examination process, exhibits in its activities and sponsorship some elements of EFRAG. The organization's Executive Board and the members of the National Accounting Standards Board, contained within the organization, include important representatives from industry firms and associations, major accounting firms and government. Institutions represented include Lukoil, Avtovaz, Russian Social Organization of Small and Medium Sized Enterprises "Opora Rossii," Association of Regional Banks RF ("Association "Russia"), the Russian offices of KPMG, Ernst\&Young, Deloitte, and PWC and the influential Russian Auditing Firm FKB, the Russian technology firm "AFK" and the Duma committee on Taxation. Many of these organizations are already listed in Table I as potential Russian counterparts to EFRAG's sponsorship organizations. 
The EFRAG comparison underscores the importance of NSFO as Minfin's and the Russian government's potential expert advisory body for IFRS and accounting standard setting more generally in Russia. NSFO is a highly proactive, high-powered professional organization with indications of strong institutional backing. These are characteristics of EFRAG, as well.

EFRAG's advisory role for the EU countries and beyond is also consistent with the notion of Moscow and the Russian Federation as an important regional center. With some notable exceptions, the majority of the former republics of the Soviet Union, sometimes characterized as the Commonwealth of Independent States (CIS) recognize Russia as an important political, economic and scientific presence. The concern of Minfin with possessing the copyright to the Russian version of IFRS and having an expert body capable of examining and endorsing these documents may represent an opportunity for Russia to play an influential advisory role for many of its former republics where the Russian language is likely to be the preferred language for local auditors and accountants in applying IFRS to the preparation of financial reporting and the auditing of such reports. As noted above, eight of Russia's former republics still have accountants and auditors who belong to the old Moscow based International Association of Accountants and Auditors "Sodruzhestvo" (AAAS).

Unlike EFRAG, which simply coordinates with the local country standard setting bodies, NSFO itself plays the role of standard preparer, as advisor to Minfin. In both Australia and Canada, the standard setting bodies have a strong connection with all of the major accounting and auditing professional organizations. These bodies are, for the most part, comprised of professional public accountants and other financial professionals. It is very important that EFRAG members act, as their organizational description indicates, as individuals concerned primarily with achieving reporting transparency and looking out for the interests of the whole nation (EFRAG, 2011). Because NSFO plays and, potentially, will play such a direct role in preparing financial accounting and reporting standards for approval of the government, it is important that it live up to its own standards and avoid the danger of operating as a prestigious elite distanced from the concerns of the mass of accounting and audit professionals.

The job will not be complete when Minfin approves the Russian language IFRS with agreement of CBR and FMSS and the entire document is placed on Minfin's website. The problem of change management in such a large migration includes providing the proper training and infrastructure for Russian management accountants who will prepare the financial statements and Russian auditors who will audit them.

\section{CONCLUSION}

This paper set out to examine the current process of Russia's movement toward adoption of IFRS within the context of Russian cultural, governmental and private sector organizations and consider examples from outside Russia of competent and responsive local standard setting bodies and supportive institutional infrastructure that will be needed by Russia to achieve its IFRS aspirations. The issue of whether Russia could achieve all this on the tight time frame it has chosen was specifically addressed.

Russia may be moving swiftly toward partial adoption of IFRS for calendar and fiscal year 2012. The success of this process is, however, less to be measured by meeting its immediate deadlines than by the care with which Russia's expert body considers and discusses all implementation issues connected with any of the IFRS documents they are examining for Russia and the ongoing process of IFRS examination and problem solving as IFRS continues to evolve. It also will depend on how well the Russian Ministry of Finance and its two governmental colleague institutions the Central Bank and the Federal Financial Markets Service can collaborate effectively. What is needed is that a stable relationship be established between the government and standard preparing advisory bodies like NSFO and other professional accounting organizations. Partial, and even full adoption of IFRS, is only the beginning of a dynamic standard setting process that will continue as the IASB continues to evolve IFRS. This will require a supporting infrastructure where dialogue with the IASB and flexibility will be critical factors. It remains to be seen whether the Russian Federation's tendency to create highly formal, procedural legalistic processes for approving IFRS will permit such flexibility.

Russia has highly talented and educated professionals to meet the tasks ahead. It is hoped that the NSFO in its future actions and policies, will show itself to be a strong, independent and dedicated advisory organization 
acting in consort with Minfin on behalf of Russian accountancy and the Russian people. Minfin, itself must continue to pursue a reformist policy with regard to the implementation and evolution of IFRS on Russian soil. Ultimately, the real stakes in this venture will be transparent, reliable financial reporting that will inspire confidence in the users of Russian financial statements worldwide. We look forward with cautious optimism to the continued success of IFRS proliferation in Russia. ${ }^{1}$

\section{AUTHOR INFORMATION}

David Borker has a $\mathrm{PhD}$ from Yale combined with a Master of Accounting/MBA from Ohio State University and an A.B. from Cornell. By his academic and corporate/consulting experience, Dr. Borker is uniquely suited for accounting and business research on Russia, the CIS republics and Eastern Europe. A native speaker of English, he is fluent in Russian, German and Czech and uses numerous other languages in his research. Dr. Borker has extensive experience as an academic consultant and a businessman working in Russia, Eastern Europe and the CIS. He teaches accounting and management at Manhattanville College and is a licensed CPA. E-mail: David.Borker@mville.edu.

\section{REFERENCES}

1. $\quad$ AAAS. (2011). International Association of Accountants and Auditors "Sodruzhestvo" (AAAS). Retrieved from http://www.cisaaa.org/eng/default.asp.

2. AASB. (2011). Australian Accounting Standards Board. Retrieved from http://www.aasb.gov.au/home.aspx.

3. AcSB. (2011). ACsB, Charted Accountants of Canada, 2011. ACsB, Charted Accountants of Canada, 2011. Retrieved from. http://www.acsbcanada.org/.

4. AcSB. (2011). Liaison with the IASB and Other Accounting Standard Setters. AcSB. Retrieved from http://www.acsbcanada.org/international-activities/index.aspx.

5. $\quad$ ARB. (2011). Association of Russian Banks . Retrieved from http://www.arb.ru/site/eng/.

6. AS. (2011). Associyaciya Regional'nykh Bankov. Retrieved from http://www.asros.ru/.

7. BUSINESSEUROPE. (2011). BUSINESSEUROPE. BUSINESSEUROPE. Retrieved from http://www.businesseurope.eu/Content/Default.asp?PageID=613.

8. $\quad$ Buza, G. (2006, December 11). Neofical'nyy bukhuchet. 46.

9. Australia. (2011). Commonwealth Consolidated Acts, Corporations Act 2001, July 1, 2011. Retrieved from http://www.austlii.edu.au/au/legis/cth/consol_act/ca2001172/.

10. CEA. (2011). The European Iinsurance and Reinsurance Federation. Retrieved from http://www.cea.eu/about-the-cea.

\footnotetext{
${ }^{1}$ As an update, since the conclusion of this paper, certain events have occurred worthy of mention. The sudden resignation in late September 2011 of Alexei Kudrin, the brilliant economist who as Minister of Finance for the last eleven years has championed the cause of IFRS, raises questions about future continuity of these efforts. Nonetheless, since Kudrin's resignation, the IFRS adoption process envisioned by Kudrin has continued to unfold successfully. On October 10, 2011, all IFRS documents were successfully endorsed by the NSFO and sent to Minfin for approval. The documents were approved by the Minfin's acting Minister of Finance with co-approval from the Russian Central Bank and the Federal Financial Markets Service in Order 160n, establishing IFRS as the reporting basis for all consolidated public companies in the Russian Federation. On November 28, 2011, Order 160n was forwarded to the Ministry of Justice for registration as law Documents downloaded from Ministry of Finance Website on January 4, 2012]. On December 12, 2011, Minfin designated the Russian Journal Bukhgal'terskiy Uchet (Accounting) as the place for publication of IFRS. These actions appear to enable the Russian Federation to institute reporting in accordance with IFRS for all Russian consolidated public companies for fiscal year 2012 (Minfin, Order n. 160n, 2011)

An additional update relevant to our discussions of the relationship between MinFin and nongovernmental bodies involved in preparing accounting standards is the passage of a new Law on Accounting which became effective on October 29, 2011 (Rossiiskaya_Federaciya, 2011). This law, which replaces the Accounting Law of 1996, addresses, among other things, many of the issues discussed on this article on the relationship of the state authorized organ for federal accounting standards, currently MinFin, and nongovernmental organizations involved in accounting standard preparation, such as NSFO. The new law calls for the formation of a Council on Accounting Standards composed of non-governmental experts from non-government organizations.
} 
11. EACB. (2011). Europran Association of Co-operative Banks. Retrieved from http://www.eurocoopbanks.coop/.

12. EBF. (2011). The European Banking Federation. The European Banking Federation. Retrieved from http://www.ebf-fbe.eu/.

13. EFAA. (2011). European Federation of Accountants and Auditors (EFAA). European Federation of Accountants and Auditors (EFAA). Retrieved from http://www.efaa.com/EFAA,-,Overview,30.html.

14. EFRAG. (2011). EFRAG Facts. Retrieved from http://www.efrag.org/Front/c1-262/EFRAG-Facts.aspx.

15. Ernst\&Young. (2009). IFRS, US GAAP and RAP, Comparison and Basics. Ernst\&Young.

16. ESBG. (2011). European Savings Bank Group. European Savings Bank Group. Retrieved from http://www.savings-banks.com/PortalHome.aspx.

17. FASB. (2002). Convergence with the International Accounting Standards Board (IASB). FASB. Retrieved October 29, 2002, from http://www.fasb.org/intl/convergence iasb.shtml.

18. FEE. (2011). Introduction to FEE. Fédération des Experts-comptables Européens. Retrieved from http://www.fee.be/aboutfee/default.asp?library_ref=1\&category ref=1\&content ref $=82$.

19. Financial_Standard_Forum. (2010). Financial Standards Forum. Retrieved from http://estandardsforum.org/.

20. Gethin, H. (2006). Russia's Road to IFRS. Accounting ands Business World Congress of Accountants, 2627.

21. Horwitz, B. (1963, October). Depreciation and Cost Stability in Soviet Accounting. The Accounting Review, 38(4), 819-826.

22. IASB. (2011). Adoption of IFRS. Retrieved October 23, 2011, from http://www.ifrs.org/Use+around+the+world/Use+around+the+world.htm.

23. IASB. (2011). The Move Toward Global Standards. IASB. Retrieved October 23, 2011, from http://www.ifrs.org/Use+around+the+world/Use+around+the+world.htm.

24. IMF. (2010). Russian Federation: Financial Sector Stability Assessment Update. Washington, DC: IMF.

25. IPAR. (2011). Institute of Professional Accountants and Auditors of Russia. Institute of Professional Accountants and Auditors of Russia. Retrieved from http://www.ipbr.org/?page=english.

26. IPP. (2010). Fond NSFO napravil v Minfin pis'mo, v kotorom vyrazil "konceptual'noe nesoglasie” s zakonoproektom “Ob ofical'nom bukhgalterskom uchete.”. Institut Problem Predprinimatel'stva. Retrieved from http://www.ippnou.ru/lenta.php?idarticle $=002703$.

27. MinFin. (2004). Order No. 180 Concept of the Development of Accounting and Financial Reporting in the Russian Federation for the Mid-term. Retrieved from http://www.ipbr.org/?page=documents\&documents=np\&np=concept.

28. Minfin. (2011). " 14.06.2011 Vysazyvaniya A.L. Kudrina na zasedanii Prezidiuma Pravitel'stva RF. Ministry of Finance. Retrieved June 14, 2011, from . http://minfin.ru/ru/press/speech/index.php?id4=13123.

29. Minfin. (2011). Informacionnoe soobshchenie: O zaklyuchenii soglasheniya ob ekspertize primenimosti MSFO I Raz'yasneniy MSFO,. Ministry of Finance. Retrieved from http://www1.minfin.ru/ru/accounting/mej_standart_fo/index.php?id4=13455.

30. MinFin. (2011). Informaciya o khode priznaniya MSFO I ikh raz'yasneniy na territorii RF. Ministry of Finance. Retrieved December 10, 2011, from http://www1.minfin.ru/ru/accounting/mej_standart_fo/.

31. Minfin. (2011). Order n. 160n. Ministry of Finance. Retrieved from http://www1.minfin.ru/ru/accounting/mej_standart_fo/.

32. MinFin. (2011). Prikaz MinFina Rossii ot 08-04-2011 No. 41. Moscow: Ministry of Finance. Retrieved from http://www1.minfin.ru/common/img/uploaded/library/2011/04/Prikaz_MF_41n.PDF.

33. Minfin. (2011, July 8). Soobschenie ob opredelenii ekspertnogo organa dlya provedeniya ekspertizy primenimosti dokumentov, vkhodyashchikh v sostav MSFO na territorii RF. Mezhdunarodnye standarty finansovoy otchetnosti. Retrieved from http://www1.minfin.ru/ru/accounting/mej_standart_fo/index.php?id4=13337.

34. PricewaterhouseCoopers Russia. (2009). Doing Business and Investing in the Russian Federation - 2009. PricewaterhouseCoopers. Retrieved from http://www.pwc.ru/en/doing-business-in-russia/index.jhtml.

35. PWC. (2011, June 15). Russia to Adopt IFRS Next Year. The Accountant, p. 1. Retrieved from http://www.vrl-financial-news.com/accounting/the-accountant/issues/ta-2011/ta-6091/russia-to-adopt-ifrsnext-year.aspx. 
36. RCA. (2011). Russian Collegium of Audiitors. Retrieved from http://waccounting.net/associations/russiancollegium-auditors.

37. Rossiiskaya_Federaciya. (2011). Federal'nyi Zakon o Bukhgalterskom uchete. Rossiiyskaya_Federaciya.

38. Russian_Federation. (2010). Federal Law No. 208-FZ On Consolidated Financial Statements. Retrieved from http://www.minfin.ru/common/img/uploaded/library/2011/03/Consolidation_Law_eng.pdf.

39. Russian_Federation. (2011). Government of the Russian Federation Resolution No. 107 of 25 February 2011 Approval of Regulations Governing the Endorsement of International Financial Reporting Standards and Interpretations of International Financial Reporting Standards with a view to. Retrieved from http://www.iasplus.com/europe/1103russianifrsendorsementenglish.pdf.

40. SEC. (2008). Roadmap for the Potential Use of Financial Statements Prepared in Accordance with International Financial Reporting Standards by U.S. Issuers. Security and Exchange Commission. Retrieved from http://www.sec.gov/rules/proposed/2008/33-8982.pdf.

41. Tohmatsu. (2009). Deloitte Touche. Retrieved from http://www.iasplus.com/europe/0909doingbusinessrussia2009.pdf.

42. VSS. (2011). All Russian Union of Insurers. Retrieved from http://www.ins-union.ru/. 